\begin{tabular}{ccc}
\hline Journal of Economics and Business Aseanomics (JEBA) & \\
Volume 3 No. 1, Januari- Juni 2018 & P-ISSN $2527-7499$ \\
Jurnal home page: htp//www.jurnalakademikjeba.yarsiac.id & E-ISSN 2528 - 3634 \\
\hline
\end{tabular}

\title{
STRATEGI PENGAMBILAN KEPUTUSAN DALAM PEMECAHAN MASALAH (STUDI KASUS PADA BANK XYZ CABANG TAJUR HALANG CIANJUR JAWA BARAT)
}

\author{
${ }^{1)}$ Mukhtadi ${ }^{2)}$ Mohammad Rizki \\ ${ }^{1}$ Unhan (Universitas Pertahanan) \\ ${ }^{2}$ Kalbis Institute (Managed By Binus)
}

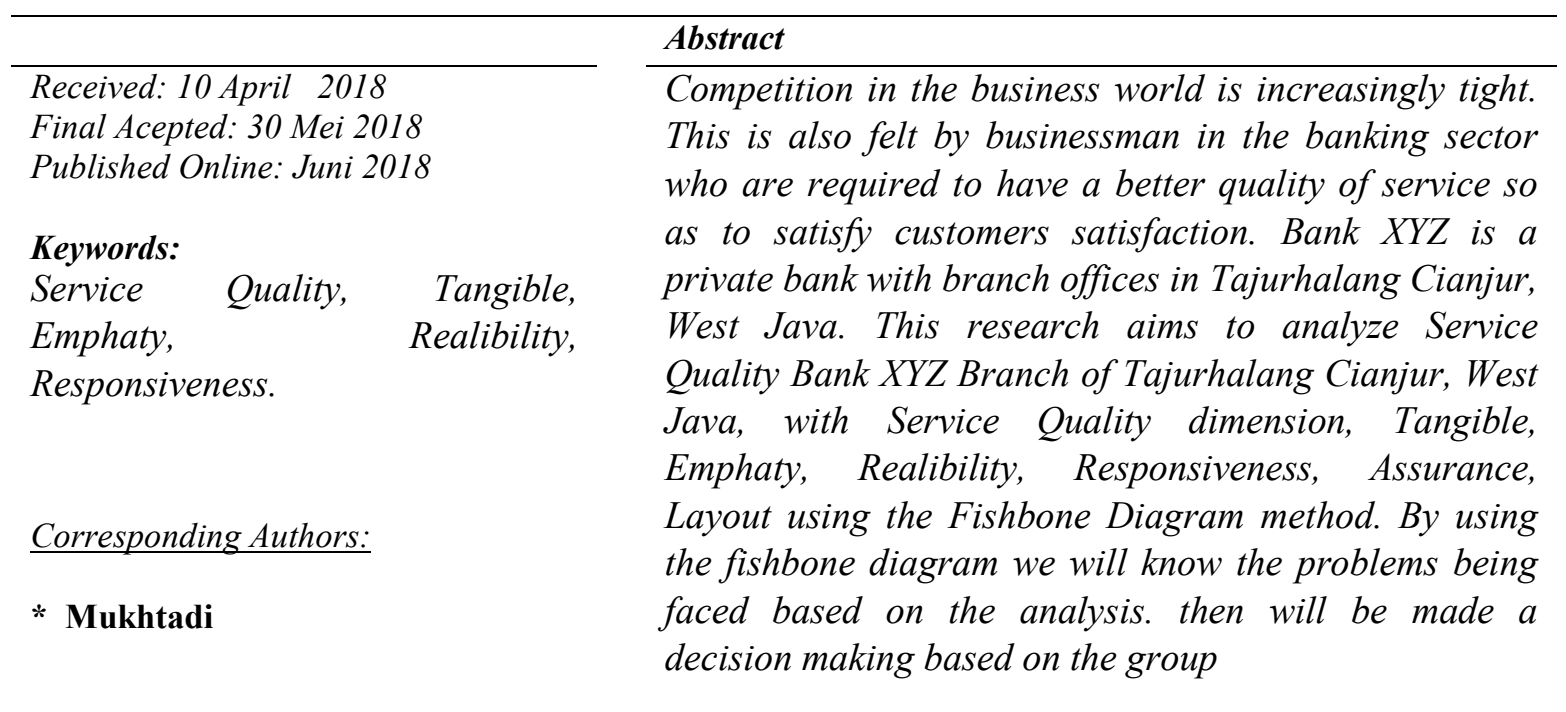

Copyright JEBA 2018., All rights reserved

\begin{abstract}
ABSTRAK
Persaingan di dunia bisnis saat ini semakin ketat. Hal ini juga dirasakan para pelaku bisnis di bidang perbankan yang dituntut untuk mempunyai kualitas pelayanan yang lebih baik sehingga mampu memuaskan kepuasan nasabahnya. Bank XYZ merupakan Bank swasta yang berkantor cabang di Tajurhalang Cianjur Jawa Barat. Penelitian ini bertujuan untuk menganalisa kualitas pelayanan Bank XYZ Cabang Tajurhalang Cianjur, Jabar, dengan dimensi, yaitu Bukti fisik, Empati, Kehandalan, Cepat tanggap, Jaminan, dan Lingkungan menggunakan metode Fishbone Diagram. Dengan menggunakan fishbone diagram kita akan mengetahui permasalahan yang sedang dihadapi berdasarkan analisis. kemudian akan dibuat decision making berdasarkan kelompok.
\end{abstract}

Kata Kunci: Service Quality, Tangible, Emphaty, Realibility, Responsiveness. 


\section{PENDAHULUAN}

Tugas strategis seorang pimpinan adalah mengambil keputusan, maka seorang pimpinan dituntut punya kemampuan dalam mengambil keputusan, karena dari keputasan tersebutlah akan menentukan langkah selanjutnya, keputusan yang cepat tepat dan benar akan membawa kesuksesan suatu organisasi baik organisasi profit maupun non profit, begitu juga sebaliknya keputusan yang tidak tepat akan beresiko terhadap langkah berikutnya.

Sudarmo dalam Anwar (2014) berpendapat bahwa keputusan terkait dengan ketetapan atau penentuan suatu pilihan yang diinginkan. Bagian tersulit dari proses pengambilan keputusan adalah memisahkan gejala dari masalah. Dengan demikian pengambilan keputusan secara jernih akan mampu mengidentifikasi langkah yang harus diambil. Pengambilan keputusan merupakan suatu proses pemilihan alternatif terbaik dari beberapa alternatif secara sistematis untuk ditindaklanjuti (digunakan) sebagai suatu cara pemecahan masalah.

Keputusan harus dapat menjawab pertanyaan tentang apa yang dibicarakan dalam hubungannya dengan perencanaan. Kemudian keputusan dapat pula berupa tindakan terhadap pelaksanaan yang sangat menyimpang dari rencana semula.

Kemampuan seseorang untuk membuat suatu keputusan sangat dipengaruhi oleh besarnya wewenang yang diberikan atasan. Tetapi yang paling penting bukanlah banyak atau sedikitnya wewenang, melainkan apakah orang tersebut dapat menggunakan wewenang yang telah diberikan kepadanya untuk membuat keputusan yang terbaik. Prinsip ini perlu digaris bawahi karena kenyataan menunjukkan bahwa orang gagal membuat keputusan yang baik, tepat pada waktunya, meskipun ia memiliki cukup wewenang, karena ia dilumpuhkan oleh rasa takut bahwa ia akan melakukan kesalahan.

Untuk mengembangkan kemampuan guna membuat keputusan yang mantap, handal, dan tepat pada waktunya, dibutuhkan beberapa bekal untuk melakukan hal itu. Pertama; dibutuhkan kemampuan nalar atau pertimbangan yang masak agar setelah meneliti semua faktor yang berhubungan dengan suatu masalah serta segenap alternatif pemecahannya, mampu menetapkan suatu pemecahan terbaik yang dapat dilaksanakan dengan lancar dan juga dituntut untuk berwawasan jauh ke depan agar dapat mengantisipasi dan merencanakan aksi dan reaksi yang akan muncul akibat keputusan 
tersebut. Kedua; harus mempunyai kepribadian kuat yang diperlukan untuk membuat keputusan terbaik pada waktu yang tepat, dan mengumumkannya juga pada waktu dan tempat yang tepat sehingga akan diperoleh hasil sesuai yang diharapkan.

Dalam tulisan ini akan diuraikan berbagai upaya yang dapat ditempuh dalam pengambilan keputusan di Bank XYZ Cabang Tajurhalang Cianjur, Jabar yang akan di deskripsikan oleh penulis, sehingga dihasilkan keputusan yang cepat dan tepat.

Tujuan penulisan ini adalah:

1. Menganalisis permasalahan atas Layanan di Bank XYZ

2. Menganalisis strategi pemberdayaan Man, Material, Methode, Machine dan Layout sebagai solusi mengatasi masalah peningkatan layanan

3. Menganalisis Pengambilan Keputusan yang tepat untuk meningkatkan Pelayanan

\section{KAJIAN TEORI}

Membuat suatu keputusan adalah pekerjaan penting yang harus dilakukan oleh beberapa eksekutif. Keputusan yang buruk dapat merusak bisnis dan karir. Tidak semua keputusan yang buruk dapat kita perbaiki. Keputusan yang buruk dapat terjadi karena beberapa hal. Pada beberapa kasus, keputusan yang buruk dapat ditelusur kembali dari keputusan tersebut dibuat. Tetapi, kadang-kadang kesalahan tidak terletak pada proses pembuatan keputusan namun lebih pada pikiran pembuatan keputusan.

Para eksekutif dapat mencoba membiasakan diri dengan jebakan-jebakan dalam pembuatan keputusan guna untuk meningkatkan keputusan yang mereka buat dan merekomendasikan usulan pada bawahan dan rekan sekerja. Berbagai macam bentuk jebakan dalam pengambilan keputusan antara lain:

1) Anchoring Trap

Ketika mempertimbangkan keputusan, pikiran kita secara tidak sadar memberikan bobot yang tidak proporsional untuk informasi yang pertama kali diterima. Kesan awal, perkiraan atau data awal membuat suatu 'jangkar'/anchor di dalam benak. Dalam bisnis, 'jangkar' yang umum terjadi adalah peristiwa masa lalu atau tren. Harapan kita mengandalkan tren/peristiwa masa lalu tersebut agar dapat lebih akurat meramalkan masa depan namun yang terjadi adalah kecenderungan untuk memberikan terlalu banyak pembobotan untuk peristiwa masa lalu dan tidak cukup pembobotan untuk 
faktor-faktor lain yang berpengaruh di masa depan. Terutama di pasar dengan perubahan yang cepat, jangkar historis dapat menyebabkan perkiraan yang buruk dan pilihan sesat.

"Jebakan jangkar" ini mempengaruhi bagaimana manajer, akuntan, insinyur, bankir, pengacara, konsultan, analis saham dan hampir semua profesional membuat keputusan. Tidak ada yang bisa menghindari pengaruh dari jebakan ini. Namun, manajer yang menyadari bahaya jebakan ini dapat mengurangi dampaknya dengan menggunakan teknik-teknik berikut:

a) Selalu melihat masalah dari perspektif yang berbeda. Coba gunakan alternatifalternatif dan pendekatan awal jangan terpaku pada pikiran awal Anda.

b) Berpikiran terbuka. Cari informasi dan opini dari berbagai orang untuk memperluas kerangka berpikir Anda.

\section{2) The Status Quo Trap}

Kita secara bias mempengaruhi pilihan yang kita buat. Misalnya, kita masing-masing cenderung untuk melanggengkan status quo (status saat ini); itu merupakan bagian inheren dari pemikiran kita. Jauh di dalam jiwa, kita sedang melindungi diri dan menghindari risiko.

\section{3) The Sunk-cost trap}

Bias lainnya adalah kecenderungan kita untuk membuat pilihan dalam cara-cara yang membenarkan keputusan yang terakhir kali dibuat, bahkan ketika yang terakhir tidak lagi tampak valid.

Cara untuk dapat mengurangi dampak dari jebakan ini adalah salah satunya dengan mencari dan mendengarkan dengan cermat pandangan orangorang yang tidak terlibat dalam keputusan sebelumnya. Selain itu, jangan menumbuhkan budaya takut kegagalan yang mengarahkan karyawan pada meneruskan dan menutupi kesalahan-kesalahan yang sudah dibuat sebelumnya.

\section{4) The Confirming Evidence Trap}

Pemimpin kadang-kadang mencari informasi yang mendukung naluri mereka yang ada atau sudut pandang dan menghindari informasi yang bertentangan dengan naluri mereka. Perangkap ini mempengaruhi bagaimana kita untuk mengumpulkan bukti, serta bagaimana kita menafsirkannya. Akibatnya, kita memberikan perhatian terlalu 
besar pada informasi yang mendukung naluri kita tersebut dibanding informasi yang bertentangan dengan naluri tersebut.

5) The Framing Trap

Langkah pertama dalam membuat keputusan adalah untuk membingkai pertanyaan (framing). Ini juga salah satu langkah yang paling berbahaya, bagaimana Anda membingkai masalah dapat sangat mempengaruhi pilihan keputusan Anda.

6) Estimating and Forecast Trap

Suatu jebakan yang terjadi ketika kita membuat perkiraan atau peramalan. Terdapat tiga jebakan yang tidak tertentu namun berpengaruh pada cara kita membuat keputusan:

a) Overconfidence Trap

Sebagian besar dari kita terlalu percaya diri tentang kemampuan penilaian dan akurasi prediksi karena kita seringkali lebih mudah mengingat keberhasilan sebelumnya dan dengan cepat melupakan kesalahan. 'Keangkuhan' tersebut membuat kita hanya membuat range kemungkinan yang kecil/sempit.

b) The Prudence Trap

Ketika dihadapkan dengan taruhan tinggi, kita cenderung untuk menyesuaikan perkiraan atau prediksi dengan kehati-hatian hanya untuk berada di sisi yang aman. Salah satu contoh umum adalah analisa worstcase (kondisi terburuk) yang dampaknya dapat menambah biaya yang sangat besar dan tidak ada manfaat praktis. Terlalu banyak kehati-hatian bisa sama berbahayanya dengan terlalu sedikit.

c) The Recallability Trap

Bahkan ketika kita tidak terlalu percaya diri atau terlalu bijaksana, kita masih bisa jatuh ke dalam perangkap mendasarkan prediksi tentang kenangan peristiwa masa lalu (recall ability). Ingatan peristiwa dramatis meninggalkan kesan yang kuat pada pikiran kita dan dapat condong dalam upaya pengambilan keputusan di masa depan. 


\section{Fungsi dan Tujuan Pengambilan Keputusan}

Keputusan merupakan suatu pemecahan masalah sebagai suatu hukum situasi yang dilakukan melalui pemilihan satu alternatif dari beberapa alternatif. Menurut Hasan dalam Sumaryanto (2011) pengambilan keputusan sebagai suatu kelanjutan terhadap pemecahan masalah yang memiliki fungsi antara lain:

1. Pangkal permulaan dari semua aktivitas manusia yang sadar dan terarah, baik secara individual maupun secara kelompok, baik secara institusional maupun secara organisasional.

2. Sesuatu yang bersifat futuristik, artinya bersangkut paut dengan hari depan, masa yang akan datang, dimana efeknya atau pengaruhnya berlangsung cukup lama.

\section{Unsur dan Dasar Pengambilan Keputusan}

Agar pengambilan keputusan dapat lebih terarah, maka perlu diketahui setiap komponen dari pengambilan keputusan tersebut. Dalam hal ini penulis mendeskripsikannya sebagai berikut:

1. Tujuan dari pengambilan keputusan.

2. Identifikasi alternatif keputusan untuk memecahkan masalah.

3. Perhitungan mengenai faktor yang tidak dapat diketahui sebelumnya.

4. Sarana untuk mengevaluasi.

Sedangkan dasar dari pengambilan keputusan yang berlaku, yaitu:

1. Intuisi, Pengambilan keputusan yang berdasarkan atas intuisi atau perasaan memiliki sifat subjektif, sehingga mudah terkena pengaruh. Dalam pengambilan keputusan berdasarkan intusi ini, meskipun waktu yang digunakan untuk mengambil keputusan relatif pendek, tetapi keputusan yang dihasilkan seringkali relatif kurang baik karena seringkali mengabaikan dasar pertimbangan lainnya.

2. Pengalaman, Pengambilan keputusan berdasarkan pengalaman memiliki manfaat bagi pengetahuan praktis. Karena pengalaman seseorang dapat memperkirakan keadaan sesuatu, dapat memperhitungkan untung ruginya, baik buruknya keputusan yang akan diambil. 
3. Fakta, Pengambilan keputusan berdasarkan fakta dapat memberikan keputusan yang sehat, solid, dan baik. Dengan fakta, maka tingkat kepercayaan terhadap pengambilan keputusan dapat lebih tinggi, sehingga orang dapat menerima keputusan dengan lapang dada.

4. Wewenang, Pengambilan keputusan berdasarkan wewenang biasanya dilakukan oleh pimpinan terhadap bawahannya atau orang yang lebih tinggi kedudukannya kepada orang yang lebih rendah kedudukannya. Hasil keputusannya dapat bertahan dalam jangka waktu yang cukup lama dan memiliki otentisitas, tetapi dapat menimbulkan sifat rutinitas, mengasosiasikan dengan praktek diktatorial dan sering melewati permasalahan yang seharusnya dipecahkan sehingga dapat menimbulkan kekaburan.

5. Rasional, Pada pengambilan keputusan yang berdasarkan rasional, keputusan yang dihasilkan bersifat objektif, logis, lebih transparan, konsisten untuk memaksimalkan hasil atau nilai dalam batas kendala tertentu, sehingga dapat dikatakan mendekati kebenaran atau sesuai dengan apa yang diinginkan. Pengambilan keputusan secara rasional ini berlaku sepenuhnya dalam keadaan yang ideal. Pada pengambilan keputusan secara rasional terdapat beberapa hal sebagai berikut:

a. Kejelasan masalah: tidak ada keraguan dan kekaburan masalah.

b. Orientasi tujuan: kesatuan pengertian tujuan yang ingin dicapai.

c. Pengetahuan alternatif: seluruh alternatif diketahui jenisnya dan konsekuensinya.

d. Preferensi yang jelas: alternatif bisa diurutkan sesuai kriteria.

e. Hasil maksimal: pemilihan alternatif terbaik berdasarkan atas hasil ekonomis maksimal.

\section{Keuntungan Keputusan Yang Tepat}

1. Kita akan dipercaya sepenuhnya sebagai seorang pemimpin yang tangguh.Pihak atasan maupun bawahan akan memberikan kepercayaan mereka atas kualitas dan kemampuan kita selaku seorang pemimpin, jika kita mampu membuktikan pada mereka bahwa kita mampu membuat perkiraan yang tepat dan cepat tentang suatu situasi serta mampu mengambil keputusan terbaik tepat pada waktunya. Untuk membuat keputusan dan tepat pada waktunya, kita perlu mengumpulkan semua fakta dan informasi untuk dianalisis dan disaring guna merumuskan suatu kepastian pemikiran dan langkah untuk 
menyampaikan instruksi secara meyakinkan, sebagai eskpresi bahwa kita memang melakukan sesuatu yang benar.

2. Orang lain akan mempercayai keputusan dan instruksi kita.

Apabila kita mampu melakukan penalaran secara logis, lalu memanfaatkannya sebagai dasar untuk membuat keputusan yang cepat dalam situasi apapun, maka orang lain akan mempercayai sikap, keputusan, pengarahan, pendapat, serta instruksi kita. Mereka akan percaya kepada kita dan terkesan oleh pertimbangan kita yang masak dan terarah, selanjutnya mereka pasti bersedia melakukan sesuatu yang terbaik untuk kita.

3. Kita akan dikenal sebagai ahli pemecah masalah.

Tindakan positif dan tepat sangat berpengaruh dalam membangun kepercayaan orang lain kepada kita. Kita akan mempunyai reputasi sebagai seorang ahli dalam memecahkan masalah dan membereskan segala sesuatu yang mengganggu serta dikenal sebagai orang yang bisa membuat sesuatu terlaksana dengan baik. Hal ini akan mengangkat status kita dalam organisasi dan membawa kita di kedudukan yang lebih baik.

4. Kita akan terhindar dari belenggu frustrasi.

Kegagalan dalam memusatkan pikiran merupakan sumber frustrasi yang berbahaya, hal ini berlaku dalam segala bidang kehidupan, termasuk yang menyangkut pemecahan masalah pribadi dalam kehidupan kita setiap hari. Jika kita mampu melatih diri menggunakan cara ilmiah untuk memecahkan masalah dan membuat keputusan yang handal dan tepat waktu, maka kita akan terhindar dari sergapan rasa frustrasi. Selain itu kita akan mempunyai rasa percaya diri dan kemampuan menghadapi tekanan.

\section{Faktor Yang Mempengaruhi Pengambilan Keputusan}

Dalam pengambilan keputusan terdapat beberapa faktor yang mempengaruhi, yaitu:

1. Posisi kedudukan, Dalam kerangka pengambilan keputusan, kedudukan seseorang dapat dilihat, apakah ia sebagai pembuat keputusan, penentu keputusan, ataukah karyawan.

2. Masalah, Masalah ialah apa yang menjadi penghalang untuk tercapainya tujuan, yang merupakan penyimpangan dari apa yang diharapkan, direncanakan atau dikehendaki dan harus diselesaikan. Sebenarnya, masalah tidak selalu dapat dikenal dengan segera, ada yang memerlukan analisis, ada pula yang bahkan memerlukan riset tersendiri. 
3. Situasi, Adalah keseluruhan faktor dalam keadaan, yang berkaitan satu sama lain, dan yang secara bersamaan memancarkan pengaruh terhadap kita beserta apa yang hendak kita perbuat. Situasi ini ada yang bersifat tetap dan ada juga yang berubah.

4. Kondisi, Merupakan keseluruhan dari faktor yang secara simultan menentukan daya gerak, daya berbuat atau kemampuan kita. Sebagian besar faktor tersebut merupakan sumber daya.

5. Tujuan, Tujuan yang hendak dicapai, baik tujuan perorangan, tujuan unit (kesatuan), tujuan organisasi, maupun tujuan usaha, pada umumnya telah tertentu / telah ditentukan.

\section{Pengambilan Keputusan Kelompok}

Triono (2011) mengemukakan pengambilan keputusan kelompok merupakan upaya untuk menyatukan pemikiran anggota kelompok terhadap persoalan yang dihadapi. Kreativitas individual selain ditentukan oleh bakat dasar individu,dipengaruhi juga oleh sikap organisasi terhadap kreativitas. Organisasi yang memilki kecenderungan memanipulasi kreativitas individual akan menekankan ide kreatif. Kreativitas dalam kelompok merupakan hal lain. Bahkan apabila individu dalam kelompok tersebut merupakan individu yang kreatif sekalipun, mereka harus belajar untuk menyatukan kreativitasnya sebagai kreativitas kelompok.

Perdebatan, skeptisisme,bahkan kritikan dilontarkan buak terhadap diri sendiri, melainkan terhadap orang lain. Pada budaya simbolis bersifat konteks yang lebih tinggi, seperti di Indonesia, diskusi eksternal diharapkan menghasilkan hal yang lebih baik menghadapi kendala tersebut, yaitu 1) kritikan adalah menyakitkan dan tidak sesuai budaya, dengan akibat orang merasa enggan melakukan kritikan yang membangun. 2) individu merasa tidak tahan dengan kritikan. Untuk menghindari hal tersebut, langkah yang mungkin ditempuh adalah sebagai berikut:

1. Individu dilarang melakukan kritikan

2. Individu dipaksa untuk menyajikan alternative yang berbeda.

3. Evaluasi dilakukan dengan membahas kekuatan dan kelemahan setiap alternatif.

Penolakan kelompok dalam menerima ide baru pada umunya tejadi karena tidak adanya budaya atau norma yang mendukung untuk berfikir kreatif dan inovatif. Apabila ditarik akar permasalahannya maka akan muncul sejumlah penyebab. Pertama, tidak terbiasa dengan perbedaan. Kedua, tidak adanya iklim pengambilan keputusan yang 
mendukung. Ketiga, tidak adanya fasilitas terhadap kolaborasi, terlebih ketika terjadi situasi konflik. Keempat, disebabkan oleh tidak terbiasa melakukan active listening, dimana individu berusaha untuk memahami apa yang dikatakan orang lain dan kemudian berusaha untuk membuat perbaikan atas usulan yang dibuat orang lain.

\section{Strategi Pengambilan Keputusan Kelompok}

Menurut Hirokawa dan Gouran dalam Rismayanti (2016) menjelaskan dalam pengambilan keputusan kelompok terdapat tiga jenis komunikasi, yaitu:

1. Promotive, merupakan interaksi yang menggerakkan kelompok sesuai dengan tujuan organisasi.

2. Disruptive, interaksi yang mengalihkan, memperlambat atau menghambat, atau menghalangi anggota kelompok dalam melaksanakan empat fungsi tugas.

3. Counteractive, yaitu interaksi yang digunakan oleh anggota kelompok untuk mengembalikan kelompok pada tujuan awal.

Sejalan dengan pernyataan tersebut, maka peneliti menyimpulkan dalam pengambilan keputusan, terdapat berbagai cara dan gaya yang dilakukan sebuah organisasi. Berbagai gaya dan cara ini dapat dilakukan oleh seluruh anggota organisasi maupun pemimpin organisasi tersebut. Pengambilan keputusan baik secara keseluruhan organisasi maupun hanya lewat pemimpin memiliki pengaruh dalam keputusan itu sendiri

Berbagai pihak yang terkait dalam pengambilan keputusan dan ikut dalam diskusi dalam rangka pemecahan masalah diharapkan dapat melaksanakan setiap keputusan yang telah diambil dan disepakati bersama. Kehadiran pihak terkait ini menjadi penting karena dengan demikian sebuah masalah dapat dilihat dari berbagai sisi dan keputusan yang diambil tidak merugikan salah satu atau kedua pihak. Kesepakatan dalam organisasi dan pengambilan keputusan diharapkan merupakan keputusan terbaik demi terwujudnya tujuan bersama.

\section{Kerangka Berpikir}

Berdasarkan landasan teori yang sudah dilakukan terlebih dahulu, maka disusun kerangka pemikiran untuk penelitian pada gambar dibawah ini: 




Gambar 1.

Kerangka Penelitian

\section{METODE PENELITIAN}

Metode penelitian ini adalah research kualitatif, melalui kajian pustaka (Library Research) mempelajari dari berbagai sumber terkait dan melakukan penelusuran terhadap buku-buku, dokumen-dokumen, sumber internet serta referensi lainnya, pengamatan langsung (direct observation) dan tidak langsung (indirect observation) yang relevan dengan masalah yang penulis bahas dalam penelitian ini, lalu menganalisis berdasarkan kaidah penelitian dan dikutip mater-materi yang penting dan yang dicari dan disimpulkan selanjutnya ditampilkan dalam tulisan agar dapat di jadikan salah satu sumber acuan bagi dunia academik masyarakat umum dan siapapun yang berminat untuk mengetahui tentang strategi pengambilan keputusan untuk menyelesaikan masalah

Salah satu penekanan utama dalam metode penelitian kualitatif adalah penggunaan interpretasi untuk membangun sebuah konstruksi sosial dengan asumsi bahwa sebagai makhluk sosial realitas adalah produk yang tiada henti (Lindlof, dalam Nabi dan Oliver, 2009) penelitian kualitatif lebih fokus pada proses interaksi dari pada variabel, kata kuncinya adalah otentitas dan bukan reliabilitas, nilai-nilai boleh dihadirkan jadi tida bebas nilai, bisa merupakan analisis tematik, kasusnya boleh kecil dan terbatas, dan peneliti dapat terlibat dalam proses penelitianitu (Neuman, 2014) 
Riset kualitatif ditujukan untuk menjelaskan fenomena secara dalam melalui pengumpulan data yang sedalam-dalamnya (Krisyantono, 2010)

Metode penelitian pada dasarnya merupakan cara ilmiah untuk mendapatkan data dengan tujuan dan kegunaan tertentu (Sugiyono, 2014), dari teori Sugiyono ini diperoleh empat kata kunci yaitu cara ilmiah, data, tujuan dan kegunaan, lebih lanjut disampaikan metode penelitian dapat diklasifikasikan berdasarkan tujuan dan tingkat kealamiahan obyek yang akan diteliti. Penelitian deskriptif dimaksudkan untuk menyelidiki keadaan, kondisi, atau hal lain, yang hasilnya dipaparkan dalam bentuk laporan penelitian. (Arikunto 2014) Menurut (Moleong 2014) bahwa penelitian deskriptif menekankan pada data berupa kata-kata, gambar, dan bukan angka-angka yang disebabkan oleh adanya penerapan metode kualitatif, karena itu (Sugiyono 2014) menyampaikan penelitian deskriptif dilakukan untuk mengetahui keberadaan nilai variabel mandiri, baik satu variabel atau lebih tanpa membuat perbandingan atau menghubungkan dengan variabel lain. Sifat deskriptif analitik dari penelitian kualitatif ditujukan terhadap data yang dipaparkan dalam bentuk kata-kata atau gambar daripada angka-angka, hasil penelitian merupakan kutipankutipan dari data untuk mengilustrasikan dan menyediakan bukti presentasi.

Di dalam penelitian kualitatif data dikumpulkan terutama oleh penelitian sendiri secara pribadi dengan memasuki lapangan, mengumpulkan informasi. Sumber data yang digunakan dalam penelitian ini berasal dari : (1) Data Primer, yaitu data yang diperoleh langsung dari sumbernya; (2) Data Sekunder, yaitu data tambahan yang sudah diolah dan diperoleh dari kepustakaan dengan mempelajari literatur dan bacaan yang berhubungan dengan permasalahan yang dibahas serta sumber-sumber yang mendukung. Teknik pengumpulan data yang dilakukan meliputi:

1) Wawancara, yaitu mengumpulkan data dengan cara melakukan tanya jawab dengan para pengambil kebijakan dalam pengambilan keputusan pada Bank XYZ Tajurhalang Citeureup Bogor Jawa Barat. Dalam hal ini narasumber tersebut dianggap paling menguasai dan memahami data, informasi, ataupun fakta dari objek penelitian tersebut;

2) Dokumentasi, dalam hal ini peneliti memperoleh data dari server untuk mendapatkan data yang berhubungan dengan penelitian;

3) Observasi, yaitu melakukan pengamatan langsung terhadap objek yang diteliti sesuai dengan tujuan penelitian. 
Satuan kajian berkaitan dengan batasan yang akan dilakukan di dalam proses penelitian yang didasarkan pada rumusan penelitian. Untuk meningkatkan layanan pada Bank XYZ., pada penelitian ini banyak sub bab yang akan menjadi fokus penelitian adapun aspek-aspek yang diukur dalam penelitian ini yaitu : (1) Man / SDM meliputi: a) Pembuatan manual mutu yang berbasis kinerja b) Membuat pelatihan untuk karyawan baru c) Karyawan memerlukan komunikasi yang efektif agar mengerti tentang pesan pekerjaan (2) Material meliputi: a) Melakukan pengecekan ulang perlengkapan yang dikirim oleh kantor pusat b) Mengoreksi terlebih dahulu sebelum menggunakan bahan baku agar tidak terjadi pemborosan (3) Methode meliputi: a) Karyawan harus memberikan informasi pelayanan pemesanan kepada nasabah b) Perlu adanya tambahan procedure agar metode berjalan (4) Machine meliputi: a) Pemeriksaan mesin harus diperketat b) Menambah jumlah TL dan CS agar pelayanan berjalan dengan cepat (5) Layout meliputi: a) Tempat pelayanan harus bersih b) Memperluas ruang istirahat

Teknik- teknik yang digunakan adalah sebagai berikut : (1) Memahami pengambilan keputusan secara taktis untuk meningkatkan layanan dengan menggunakan analisis Fishbone Diagram; (2) Mengumpulakan data mengenai subjek penelitian untuk memahami factor-faktor yang berpengaruh terhadap peningkatan pelayanan; (3) Memahami konsep pengambilan keputusan yang strategis

diantara beberapa alternatif yang ada. Dalam kasus ini alternative tersebut adalah: Man, Material, Methode, Machine dan Layout; (4) Membandingkan penerapan pengambilan keputusan perusahaan dengan metode Fishbone Diagram ; (5)Menulis hasil laporan penelitian; (6) Menarik konklusi terhadap rumusan masalah dan memberikan pengembangan implementasi hasil penelitian.

\section{HASIL DAN PEMBAHASAN}

\section{Pemecahan masalah dalam proses pengambilan keputusan}

Proses Pengambilan Keputusan pada umumnya dimulai dengan penetapan tujuan / Objective serta variabel yang menjadi key performance indicator. Setelah tujuan akhir disepakati dan dipahami bersama, maka mulai diidentifikasi masalah yang saat ini sedang dihadapi. Dari perumusan masalah, maka akan dianalisa alternatif-alternatif solusi bagi penyelesaian masalah yang biasanya didapatkan dari proses brainstorming. Beberapa 
alternatif solusi ini kemudian dikembangkan, dianalisa dan dievaluasi dari berbagai variabel yang telah ditetapkan sebagai standar indikator keberhasilan kunci, untuk kemudian dipilih yang terbaik dan akhirnya diterapkan di lapangan. Kemudian hasil dari pelaksanaan dalam kurun waktu tertentu dievaluasi hasilnya serta dampak-dampak negatif yang terjadi segera dikendalikan dan dilakukan penyesuaian sesuai dengan kondisi praktek di lapangan.

Ada beberapa teori yang dapat digunakan sebagai strategi pemecahan masalah. Salah satu yang digunakan di Astra adalah model DMAIC Cycle yang umumnya digunakan untuk mengukur keberhasilan suatu proyek yang sedang berjalan.

DMAIC $=$ Define - Measure - Analyze - Improve dan Control

\section{Clanify VOC}

2. Translate VOC to CTQ

3. dentify Project Y

4. Define Scope of the Project

\section{Define Project Charter}
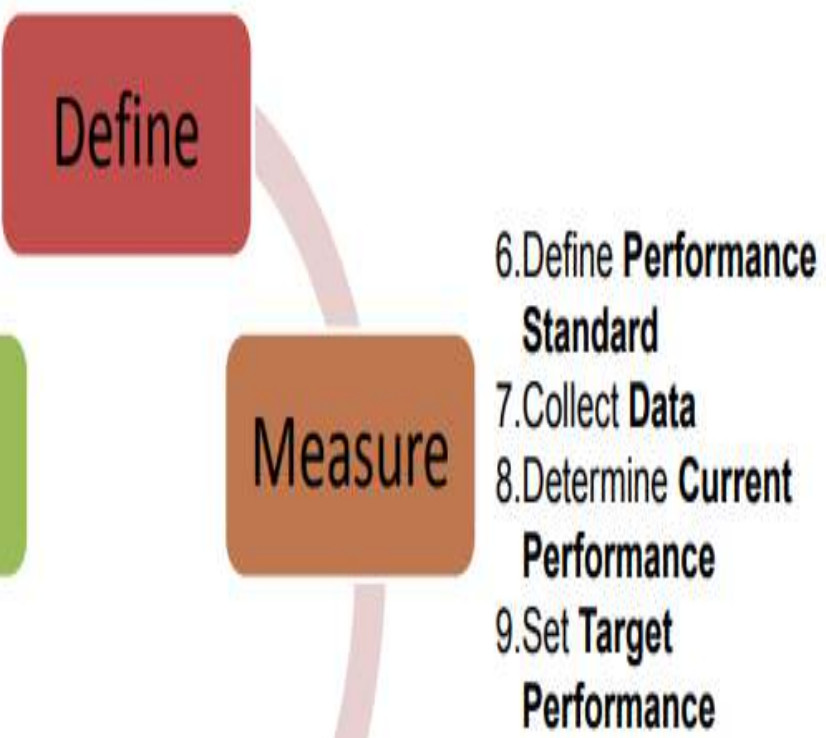

12. Generate Idea

13. Select Idea

14. Implement Idea

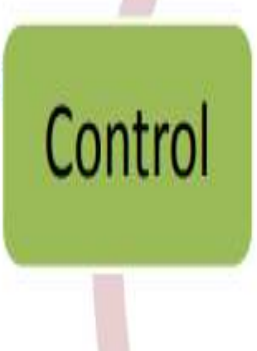

Performance

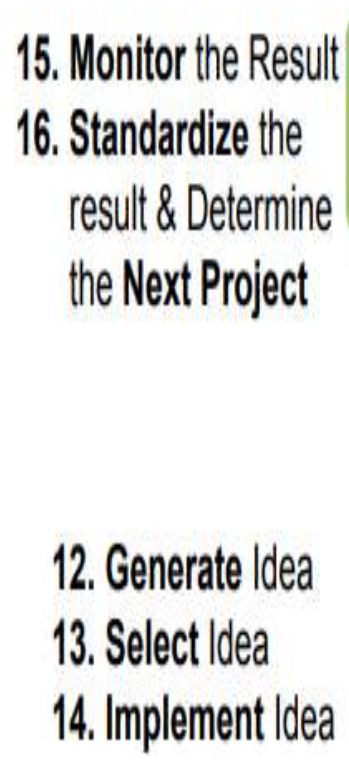

6.Define Performance

Standard

Collect Data

rermance

Set Target

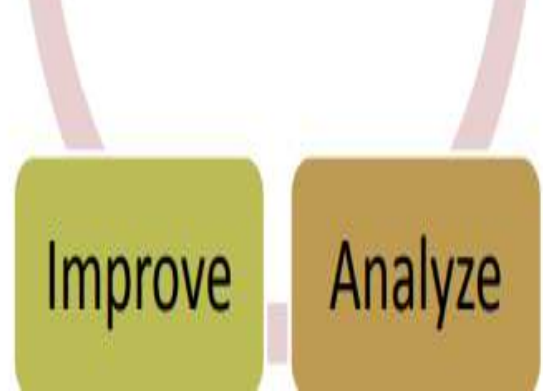

10. Conduct Gap Analysis

11. Determine Root Causes 
Pada langkah pertama Define, yaitu mengenali secara jelas apa Voice of Customer, dengan cara memahami issue utama apa yang ingin diminta perbaikan oleh customer. Misalnya akurasi waktu, kecepatan pengerjaan servis mesin, dan lain-lain. Setiap issue yang bisa diidentifikasi tersebut kemudian dibuat target kuantitatifnya.

\section{Analisis Fishbone Diagram}

1. Menentukan tema dan dasar permasalahan.

2. Menganalisis sebab dan akibat berdasarkan data dengan menggunakan fishbone analyst.

a. Menggambarkan garis horizontal dengan tanda panah pada ujung sebelah kanan dan suatu kotak di depannya yang berisi masalah yang diteliti.

b. Menuliskan penyebab utama dalam kotak yang dihubungkan ke arah garis panah utama.

c. Menuliskan penyebab kecil disekitar penyebab utama dan menghubungkannya dengan penyebab utama.

3. Menentukan setiap sebab potensial dari permasalahan dan menentukan penyebab yang paling dominan dari permasalahan yang terjadi.

4. Menentukan rencana penanggulangan untuk memecahkan permasalahan yang ada.



Gambar 2 Fishbone Diagram 
Berdasarkan gambar fishbone diagram pada gambar diatas, kemudian dapat diuraikan cara mengatasi ketidakpuasan layanan nasabah Bank XYZ Cabang Tajurhalang Cianjur, Jabar. Selanjutnya dapat diperoleh beberapa alternatif penanganan yang terkait dengan kepuasan nasabah yang dihasilkan di Bank XYZ Cabang Tajurhalang Cianjur, Jabar.

Proses Pengambilan Keputusan pada umumnya dimulai dengan penetapan tujuan / Objective serta variabel yang menjadi key performance indicator. Setelah tujuan akhir disepakati dan dipahami bersama, maka mulai diidentifikasi masalah yang saat ini sedang dihadapi. Dari perumusan masalah, maka akan dianalisa alternatif-alternatif solusi bagi penyelesaian masalah yang biasanya didapatkan dari proses brainstorming. Beberapa alternatif solusi ini kemudian dikembangkan, dianalisa dan dievaluasi dari berbagai variabel yang telah ditetapkan sebagai standar indikator keberhasilan kunci, untuk kemudian dipilih yang terbaik dan akhirnya diterapkan di lapangan. Kemudian hasil dari pelaksanaan dalam kurun waktu tertentu dievaluasi hasilnya serta dampak-dampak negatif yang terjadi segera dikendalikan dan dilakukan penyesuaian sesuai dengan kondisi praktek di lapangan.

Selanjutnya dalam tahap Improve, dilakukan brainstorming untuk mendapat ide-ide solusi dari setiap anggota tim yang terlibat proyek. Dipilih satu atau beberapa solusi terbaik yang memberi dampak terbesar bagi konsumen dan perusahaan. Proses pengambilan keputusan dalam memilih ide solusi terbaik memerlukan obyektifitas bersama. Salah satu alat bantu pengambilan keputusan disini adalah Solution Selection Matrix.

Dalam pengambilan keputusan, variabel yang paling wajib dipertimbangkan adalah cost dan benefit, dimana solusi terbaik biasanya adalah solusi dengan benefit tertinggi yang disertai dengan cost terendah. Ini disebut kategori Grand Slam. Implementasi dari alternatif ide solusi yang dipilih harus dengan Problem Identification dan Corrective Action agar tetap termonitor proses pelaksanaan sehingga perhitungan cost-benefit aktual tidak berbeda jauh dengan perencanaannya.

Berdasarkan hasil pembahasan dapat diketahui bahwa, factor Man (Manusia); karyawan kurang mentaati prosedur, kurang komunikasi antar karyawan. Dari faktor Material (Bahan Baku); kurangnya pemeriksaan kapasitas perlengkapan, ada pemborosan dalam pemakaian bahan baku. Dari factor Methode (Cara Kerja); lamanya waktu pelayanan, metode kerja yang tidak sesuai prosedur. Dari factor Machine (Mesin); 
Kurangnya pemeliharaan mesin, keterbatasan jumlah mesin dan peralatan perbaikan. Dari factor Layout (Lingkungan); Pencemaran dalam ruangan istirahat karyawan, Fasilitas yang kurang memadai.

\section{SIMPULAN}

Berdasarkan hasil penelitian yang telah dilakukan, dapat diambil beberapa kesimpulan sebagai berikut:

1. Berdasarkan hasil analisis deskriptif dapat diketahui bahwa faktor penyebab ketidakpuasan nasabah, yaitu :

a. Man (Manusia)

i. Karyawan kurang mentaati prosedur.

ii. Kurang komunikasi antar karyawan.

b. Material (Bahan Baku)

i. Kurangnya pemeriksaan kapasitas perlengkapan.

ii. Pemborosan dalam pemakaian bahan baku.

c. Methode (Cara Kerja)

i. Lamanya waktu pelayanan.

ii. Metode kerja yang tidak sesuai prosedur.

d. Machine (Mesin)

i. Kurangnya pemeliharaan mesin.

ii. Keterbatasan jumlah mesin dan peralatan perbaikan.

e. Layout (Lingkungan)

i. Pencemaran dalam ruangan istirahat karyawan.

ii. Fasilitas yang kurang memadai.

2. Berdasarkan faktor yang penulis jelaskan diatas maka dapat di atasi dengan beberapa solusi sebagai berikut:

a. (Man) Manusia, Mengadakan pelatihan bagi karyawan baru atau yang belum mengikuti pelatihan, memberikan pengarahan kepada karyawan pentingnya bekerja sesuai dengan SOP yang dilakukan oleh atasan atau kepala cabang.

b. (Material) Bahan baku, Melakukan pengecekan ulang perlengkapan yang dikirim oleh Bank pusat (memastikan perlengkapan dalam kondisi terjaga kualitasnya), 
c. (Methode) Metode kerja, Karyawan harus memberikan informasi mengenai pelayanan pemesanan kepada pelanggan, menambah jumlah customer service. Pemeriksaan perlengkapan yang diperketat, selalu pemeriksaan secara berkala, agar tidak terjadi kerusakan.

d. (Machine) Mesin, Pemeriksaan mesin harus diperketat, menambah jumlah money counter machine agar pelayanan berjalan dengan lancar dan tidak ada hambatan.

e. (Layout) Lingkungan, Memperluas ruang istirahat, dan perusahaan harus lebih memperhatikan fasilitas Bank XYZ cabang Tajurhalang Cianjur Jabar.

\section{DAFTAR PUSTAKA}

Duke, Daniel L., and Canady, Robert L. (1991). School Policy. New York: McGraw Hill, Inc.

Covey, Stephen R. (1991). The 7 Habbits of Highly Effective People New York: A Fireside Book.

David, P. E. S., R. J. Pusung, dan G. M. Margaretha. 2014. Analisis Biaya Relevan dalam Pengambilan Keputusan Menerima atau Menolak Pesanan Khusus pada CV. Manguni Perkasa. Jurnal EMBA ISSN 1907 - 9737 Vol. 9. Manado.

Fatimah, S. (2017). "Analisis Service Quality Menggunakan Metode Fishbone Diagram”. e-Proceeding of Applied Science. Bandung. Vol. 3, No. 2, hlm 193-199.

Fortuna Inti Alam. Jurnal EMBA ISSN 2303-1174. Vol.2(2): 1043-1054. Manado.

Herso, A. (2014). Proses Pengambilan Keputusan Untuk Mengembangkan Mutu Madrasah. Vol. 8, No.1, hlm 37-55.

Hargreaves, Andy., and Reynolds, David. (1989). Educational Politicies: Controversies and Qritiques. Wiltshere: The Falmer Press.

Hough, J.R. (1984). Educational Policy. New York: st. Martin's Press.

Kami, Michael J. (1988). Trigger Points. Singapore: McGraw Hill International Editions.

Kanter, Rosabeth M. (1989). When Giants Learn to Dance. New York: A Touchstone Book. Putman, Linda L., and Pacanowsky,

Kapferer, J.N. (1997), "Strategic Brand Management. Creating and Sustaining Brand Equity Long Term”, London, Kogan Pages 
Michael E. (1983). Communication and Organization. Beverly Hills: Sage Publication, Inc.

Octavianus, M. dan V.Ilat. 2014. Analisis Biaya Relevan untuk Menerima atau Menolak Pesanan Khusu pada UD Sinar Sakti. Jurnal EMBA ISSN 2303-1174. Vol.2(3) : 236-244. Manado.

Rismayanti, R. (2016). Corporate Decision Making Dalam Komunikasi Organisasi. Vol. 46, No. 1, hlm 49-62.

Rahmawati, E. D. 2010. Analisis Biaya Relevan dalam Pengambilan Keputusan Menerima atau Menolak Pesanan Khusus pada UD Sejati Mulia. Jurnal Akuntansi dan Keuangan Indonesia.

Rudianto. 2013. Akutansi Manajemen Informasi untuk Pengambilan Keputusan Strategis. Erlangga. Jakarta.

Sumaryanto. (2011). "Upaya Pengambilan Keputusan Yang Tepat”. Proceeding KMM FIK UNY. Yogyakarta, 31 Januari, hlm 1-13.

Triono, R. A. (2012). "Pengambilan Keputusan Manajerial”. Penerbit Salemba E mpat, Jakarta.

Ticualu, N. 2014. Penggunaan Informasi Akuntansi Diferensial dalam Pengambilan Keputusan Terhadap Pesanan Khusus pada CV Pyramid. Jurnal EMBA ISSN 23031174 Vol.2(1): 677-685. Manado.

Wulan, C.M., D.P.E. Saerang, dan R.J. Pusung. 2014. Analisis Biaya Relevan dalam Pengambilan Keputusan Menjual atau Memproses Lebih Lanjut.

Water, Dan. (1991). 21st Century Management. Singapore: Prentice Hall. 